\title{
Original
}

\section{A FIELD TEST ON THE CARIES PREVENTIVE EFFECT OF TEA DRINKING*}

\author{
Masao ONISI**, Norio SHIMURA***, Chikako NAKAMURA*** \\ and Makoto SATO***
}

\begin{abstract}
A cup of tea (containing about $0.49 \mathrm{mg} \mathrm{F}$ ) containing soluble fiuoride in the optimum necessary amount was recommended after every school lunch to 298 school children of Subara in Sumon, Niigata prefecture, for about 250 days from December, 1975 to November, 1976. Increment lesions which appeared at three carious predirective sites, i. e., pits and fissures, proximal, and free gingival smooth surfaces of the children of the test school in the Suhara district were compared to the lesions found at the same sites in 185 children of three control schools in the Kamijo district of the same village. Reduction rates at each site were $52.8 \%$ for the pit and fissures and $57.2 \%$ for the proximal sites, but there was no reduction at the free gingival sites.
\end{abstract}

The main routes of natural fluoride taken in our body were simplified by Arif ${ }^{1)}$ into four foodstuffs : water and salt from minerals, tea from vegetables, and fish from the animal kingdom.

In the case of fluoride in drinking water, Dean et al. ${ }^{2)}$ demonstrated that the caries prevalence in school children of the United States decreased in proportion to the fluoride concentration in the water they drank up to one ppm. Since then adjustment of the fluoride concentration in drinking water to one ppm became one of the important programs of public health planning in the United States ${ }^{8)}$ and was widely accepted in various countries, especially by the World Health Organization").

The water fluoridation technique, however, originally depends on the previously existing water supply system in urbanized areas which usually have a large enough number of dentists in their populations. But there are still many rural communities needing dentists as well as a water supply system, especially in Asian countries. Therefore, it is necessary to find another natural vehicle of fluoride. Utilization of table salt $\mathrm{t}^{5,6)}$ is a possible solution.

In the course of time, negative signals such as risks from chronic side effects of water fluoridation ${ }^{\text {? }}$ have emerged from epidemiological surveys, and fluoridation technology has to face psychological, political, and ethical obstacles ${ }^{8)}$. Whenever social anxiety occurs, it is very difficult to calm it simply by biological reasoning. For the solution of such a crisis as water fluoridation using chemical fluorides, we should consider the drinkable fluoride in tea leaves ${ }^{2)}$.

Tea fluoride was once considered as a possible surplus intake in a fluoridated community ${ }^{10,11}$. On the other hand, it has also been considered a useful natural source of fluoride ${ }^{12,13}$. Japan has

* This paper was completed from the report presented to the 26th. Annal Meeting of Japanese Society for Dental Health, October, 1977.

** Department of Oral Microbiology, School of Dentistry, University of Showa, Tokyo.

*** Department of Preventive Dentistry, School of Dentistry, Tokyo Medical and Dental University.

* 昭和大学歯学部口堙細菌学教室

**東京医科歯科大学齿学部予防歯科学教室 昭和 55 年 11 月 19 日受付 
produced tea for centuries and consumed it in the strong belief that the tea promotes health without any hazardous effect ${ }^{16}$. Previous reports from our department indicated that amound of drinkable fluoride in the tea leaves varied as widely as 15 to $1800 \mathrm{mg}$ per $\mathrm{Kg}$ dry weight ${ }^{92}$ and correlation analysis of a field survey showed a simple relation indicating a lower caries prevalence in children of a school located where there was a higher concentration of drinkable fluoride in tea leaves sampled in the same school zone ${ }^{15}$.

The present report concerns a field test of tea drinking conducted on school children of a Japanese village, Sumon.

\section{Description of Sumon ${ }^{15}$}

Sumon is a small villege among the mountains of the east central part of Niigata Prefecture, which faces the Japan Sea and belongs to the heavy snowfall zone of Japan. The southern half of the village called the Suhara district contains the basin of the Yaburuma River in its center while the northern half, through which flows, the Nishi River, is called the Kamijo district and is more hilly. The two districts developed independently but were united in one administrative body, Sumon, in 1956 (Figure 1).

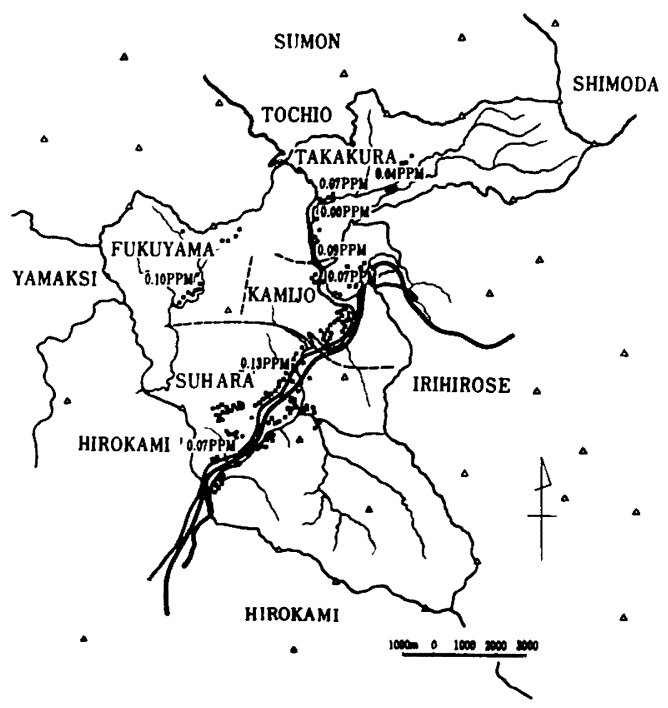

Figure 1 Sumon, Niigata Prefecture

The Suhara district has only one school zone, but the Kamijo district is composed of three primary communities called Kamijo, Takakura, and Fukuyama and their respective school zones.

Sumon has an area of $114.15 \mathrm{Km}^{2}$ of which, $18.98 \mathrm{Km}^{2}(16.63 \%)$ is utilizable for agriculture or forestry. Sumon had a population of 6317 , consisting of 3145 males and 3172 females, or 1541 households, in the 1975 census. A population of $1721(49.5 \%)$ or 1135 households $(73.6 \%)$ is engaged in agriculture and a population of $1000(28.8 \%)$ in industrial production.

A total of 532 school children go to one of the four schools. Water is supplied from eight wells and the number of users of the water supply reached to $92.3 \%$ of the total households in 1975 . Fluoride concentrations in these well waters were estimated by the Spadon method and were 0.07 $\mathrm{ppm}$ in average, ranging from 0.00 to $0.13 \mathrm{ppm}$ in $1968^{17)}$, as shown in Figure 1 . There is no dentist 
in private practice but one is working in the dental unit of the public Sumon Health Center. Many of the resident with dental trouble go to a neighboring village, Irihirose, or to Koide city.

\section{Methods of the Survey}

From 1973 to 1974 a preliminary examination was made to compare the caries in school children of both districts and the acceptability of tea drinking by the children of the 3rd to 5 th grades. It was found that caries occurrence in Kamijo children was slightly higher (Table 1), and that an additional cup of tea at every school lunch was acceptable to the children. At the reexamination for

Table 1 Susceptibility Difference between Suhara and Kamijo, 1973

\begin{tabular}{|c|c|c|c|c|c|}
\hline Schools & Class & $\begin{array}{l}\text { Number of } \\
\text { Children }\end{array}$ & Total Sites & $\begin{array}{c}\text { Number of } \\
\text { Lesions }\end{array}$ & $\begin{array}{l}\text { Susceptibility } \\
\text { in } \mathscr{6} 6\end{array}$ \\
\hline \multicolumn{6}{|c|}{ 1. Pits and Fissures } \\
\hline \multirow[t]{4}{*}{ Suhara } & $3 \mathrm{yr}$. & 61 & 999 & 251 & 25.1 \\
\hline & $4 \mathrm{yr}$. & 62 & 1201 & 322 & 26.8 \\
\hline & $5 \mathrm{yr}$. & 60 & 1429 & 386 & 27.0 \\
\hline & Total & 183 & 3629 & 959 & 26.4 \\
\hline \multirow[t]{4}{*}{ Kamijo } & $3 \mathrm{yr}$. & 59 & 915 & 277 & 30.3 \\
\hline & $4 \mathrm{yr}$. & 51 & 975 & 313 & 32.1 \\
\hline & $5 \mathrm{yr}$. & 61 & 1523 & 394 & 25.9 \\
\hline & Total & 171 & 3414 & 984 & 28.8 \\
\hline \multicolumn{6}{|c|}{ 2. Smooth Surfaces } \\
\hline \multirow[t]{4}{*}{ Suhara } & $3 \mathrm{yr}$. & 61 & 2208 & 22 & 1.0 \\
\hline & $4 \mathrm{yr}$. & 62 & 2742 & 44 & 1.6 \\
\hline & $5 \mathrm{yr}$. & 60 & 3276 & 73 & 2.2 \\
\hline & Total & 183 & 8087 & 139 & 1.7 \\
\hline \multirow[t]{4}{*}{ Kamijo } & $3 \mathrm{yr}$. & 59 & 2010 & 19 & 1.0 \\
\hline & $4 \mathrm{yr}$. & 51 & 2241 & 32 & 1.4 \\
\hline & $5 \mathrm{yr}$. & 61 & 3513 & 63 & 1.8 \\
\hline & Total & 171 & 7764 & 114 & 1.5 \\
\hline
\end{tabular}

caries increment during about one year, reduction by the tea drinking was significant in the pits and fissures, of the test children in Kamijo as compared to the control children in Suhara.

On December, 1975, the caries prevalence of children at the base line was examined in the 1st to 5th grades of the Suhara test school and the Kamijo control schools. Then the Suhara children received a cup $(100 \mathrm{ml} \pm)$ of tea after every school lunch until November, 1976. The final dental examination was conducted again on the same children, who were now in the 2nd to 6th grades, in January, 1977. Caries increments during the one year test period were compared between the test and the control schools and then reduction rates were computed to estimate the effect of the tea drinking.

Caries lesions were examined with the sharp point of a Japanese Industrial Standard No. 2 sewing needle placed in a broach holder and were decided according to the WHO Mamual of Oral Survey, 1971 ${ }^{18}$. The lesions were classified into three types depending on the localization of the three predilective sites of the caries : pit and fissure on the upper-cut surface and proximal and free gingival on the smooth under-cut surface of a dental crown. Sites on a tooth either unerupted or restored by crown were excluded, and a lesion found on two sites of a tooth was counted as two lesions. 
Before tea drinking on Suhara children, the optimum necessary fluoride taken through tea leaves should be decided. Imai ${ }^{19}$ ) surveyed the fluoride concentration of Japanese drinking water and found that half the waters sampled contained less than $0.09 \mathrm{ppm}$ fluoride, and using the known caries prevalences of school children reported by school dentists, he estimated $0.35 \mathrm{ppm}$ as the lowest but the most effective fluoride concentration for prevention of dental caries in Japanese children. Considering fluoride intoxication or counting the community fluorosis index ${ }^{20)}$, Minoguchi ${ }^{21}$ concluded $0.6 \mathrm{ppm}$ to be a border line concentration in the middle part of Japan. These data indicate that an effective but safe concentration of water fluoride would be much lower in Japan than in the midwestern United States. At the dosage of tea fluoride for the caries prevention, the selection of bancha tea leaves should be done according to Imai's estimation $(0.35 \mathrm{ppm})$ and findings at Yame ${ }^{15)}$. The third consideration for the selection and dosage of the tea fluoride is the physiologically active substances like caffain and catechol ${ }^{22)}$ in tea leaves, which contain more than 200 substances besides fluoride. In this respect, the better tea leaves recommendable to the children contain more fluoride to minimize the side effects of these physiologically active substances. Actually the tea leaves selected for the present study were commercially purchasable bancha produced at Yukimaru, Eicho, Kagoshima Prefecture. The fluoride concentration in an infusion of this bancha was estimated at $490 \mathrm{mg} / \mathrm{Kg}$ dry weight of the leaves.

To make the tea infusion, $1 \%$ of tea leaves was added to the amount of cold tap water

Table 2 Increment of Carious Lesions at Kamijo Schools

\begin{tabular}{|c|c|c|c|c|c|c|c|c|c|}
\hline \multirow{2}{*}{ Cohorts } & \multirow{2}{*}{$\begin{array}{c}\text { Number } \\
\text { of } \\
\text { Child ren } \\
1\end{array}$} & \multicolumn{3}{|c|}{ Number of Intact Sites } & \multicolumn{5}{|c|}{ Increment of Lesions } \\
\hline & & $\begin{array}{c}\text { Baseline } \\
2\end{array}$ & $\begin{array}{l}\text { Erupted } \\
\text { Teeth } \\
3\end{array}$ & $\begin{array}{c}\text { Total } \\
4\end{array}$ & On 2 & On 3 & $\begin{array}{c}\text { Total } \\
5\end{array}$ & $\begin{array}{c}\text { Average } \\
5 / 1\end{array}$ & $\begin{array}{l}\text { Rate in } \% \\
5 / 4 \times 100\end{array}$ \\
\hline \multicolumn{10}{|c|}{$2-1$. Pits and Fissures } \\
\hline $1-2 \mathrm{Gr}$. & 40 & 393 & 209 & 602 & 64 & 43 & 107 & 2.68 & 17.77 \\
\hline $2-3 \mathrm{Gr}$ & 34 & 481 & 158 & 639 & 48 & 11 & 59 & 1.74 & 9.23 \\
\hline $3-4 \mathrm{Gr}$ & 32 & 598 & 164 & 762 & 47 & 16 & 63 & 1.97 & 8.27 \\
\hline $4-5 \mathrm{Gr}$ & 34 & 828 & 180 & 1008 & 62 & 23 & 85 & 2.50 & 8.43 \\
\hline $5-6 \mathrm{Gr}$. & 45 & 1250 & 225 & 1475 & 137 & 51 & 188 & 4.18 & 12.75 \\
\hline Total & 185 & 3550 & 936 & 4486 & 358 & 144 & 502 & 2.71 & 11.19 \\
\hline \multicolumn{10}{|c|}{$2-2$. Proximal Smooth Surfaces } \\
\hline $1-2 \mathrm{Gr}$ & 40 & 550 & 326 & 876 & 6 & 0 & 6 & 0.15 & 0.68 \\
\hline $2-3 \mathrm{Gr}$ & 34 & 716 & 250 & 966 & 16 & 1 & 17 & 0.50 & 1.76 \\
\hline $3-4 \mathrm{Gr}$ & 32 & 954 & 278 & 1232 & 15 & 0 & 15 & 0.47 & 1.22 \\
\hline $4-5 \mathrm{Gr}$ & 34 & 1330 & 278 & 1608 & 26 & 2 & 28 & 0.82 & 1.74 \\
\hline $5-6 \mathrm{Gr}$ & 45 & 1854 & 452 & 2306 & 24 & 0 & 24 & 0.53 & 1.04 \\
\hline Total & 185 & 5404 & 1584 & 6988 & 87 & 3 & 90 & 0.49 & 1.29 \\
\hline \multicolumn{10}{|c|}{$2-3$. Free Gingival Smooth Surfaces } \\
\hline $1-2 \mathrm{Gr}$ & 40 & 275 & 163 & 438 & 0 & 0 & 0 & 0.0 & 0.0 \\
\hline $2-3 \mathrm{Gr}$ & 34 & 358 & 125 & 483 & 0 & 0 & 0 & 0.0 & 0.0 \\
\hline $3-4 \mathrm{Gr}$ & 32 & 477 & 139 & 616 & 1 & 0 & 1 & 0.03 & 0.16 \\
\hline $4-5 \mathrm{Gr}$ & 34 & 665 & 139 & 804 & 1 & 0 & 1 & 0.03 & 0.12 \\
\hline $5-6 \mathrm{Gr}$ & 45 & 927 & 226 & 1153 & 3 & 0 & 3 & 0.07 & 0.26 \\
\hline Total & 185 & 2702 & 792 & 3494 & 5 & 0 & 5 & 0.03 & 0.14 \\
\hline
\end{tabular}


necessary for the number of the children in a kettle and then heated. When the water boiled, heating was stopped the infusion was cooled to drinkable temperature The children would receive $0.48 \mathrm{mg}$ of fluoride each time. The total dose of fluoride taken from tea drinking during 250 school days a year would correspond to a daily intake of $0.34 \mathrm{mg}$ of fluoride for 365 days.

\section{Results}

1. Increment of caries lesions at the control Kamijo schools.

At the baseline examination, 3550 intact pits and fissures were found among 185 children in 1976, and additional 936 sites appeared during the experimental period. At the end of the experiment $502(11.1 \%)$ lesions were detected in a total of 3386 intact sites. The average caries increment was estimated at 2.71 pits and fissures per child (Table 2).

On the smooth proximal sites, similarly, 90 lesions $(1.29 \%)$ appeared on 6988 intact sites during the same period of time. The average increment of proximal lesions was 0.488 per child (Table 2).

On the free gingival sites, 5 lesions $(0.14 \%)$ or 0.027 lesions on the average appeared on 3494 intact sites (Table 2).

2. Findings at the Suhara experimental school.

In regard to the pit and fissure sites, 382 lesions (5.29) were found on 7216 intact sites during

Table 3 Increment of Carious Lesious at Suhara School

\begin{tabular}{|c|c|c|c|c|c|c|c|c|c|}
\hline \multirow{2}{*}{ Cohorts } & \multirow{2}{*}{$\begin{array}{c}\text { Number } \\
\text { of } \\
\text { Child ren } \\
1\end{array}$} & \multicolumn{3}{|c|}{ Number of Intact Sites } & \multicolumn{5}{|c|}{ Increment of Lesions } \\
\hline & & $\begin{array}{c}\text { Baseline } \\
2\end{array}$ & $\begin{array}{l}\text { Erupted } \\
\text { Teeth } \\
3\end{array}$ & $\begin{array}{c}\text { Total } \\
4\end{array}$ & On 2 & On 3 & $\begin{array}{c}\text { Total } \\
5\end{array}$ & $\begin{array}{c}\text { A verage } \\
5 / 1\end{array}$ & $\begin{array}{l}\text { Rate in } 96 \\
5 / 4 \times 100\end{array}$ \\
\hline \multicolumn{10}{|c|}{$3-1$. Pits and Fissures } \\
\hline $1-2 \mathrm{Gr}$. & . 47 & 492 & 235 & 727 & 38 & 11 & 49 & 1.04 & 6.74 \\
\hline $2-3 \mathrm{Gr}$. & 65 & 1001 & 292 & 1293 & 75 & 19 & 94 & 1.45 & 7.27 \\
\hline $3-4 \mathrm{Gr}$. & 62 & 1187 & 285 & 1472 & 46 & 6 & 52 & 0.84 & 3.53 \\
\hline $4-5 \mathrm{Gr}$ & 60 & 1369 & 298 & 1667 & 37 & 13 & 50 & 0.83 & 3.00 \\
\hline $5-6 \mathrm{Gr}$. & 64 & 1703 & 354 & 2057 & 74 & 63 & 137 & 2.14 & 6.66 \\
\hline Total & 298 & 5752 & 1464 & 7216 & 270 & 112 & 382 & 1.28 & 5.29 \\
\hline \multicolumn{10}{|c|}{ 3-2. Proximal Smooth Surfaces } \\
\hline $1-2 \mathrm{Gr}$ & 47 & 676 & 394 & 1070 & 2 & 0 & 2 & 0.04 & 0.19 \\
\hline $2-3 \mathrm{Gr}$ & 65 & 1458 & 520 & 1978 & 3 & 0 & 3 & 0.05 & 0.15 \\
\hline $3-4 \mathrm{Gr}$ & 62 & 1806 & 508 & 2314 & 14 & 0 & 14 & 0.23 & 0.61 \\
\hline $4-5 \mathrm{Gr}$. & 60 & 2104 & 484 & 2588 & 15 & 0 & 15 & 0.25 & 0.58 \\
\hline $5-6 \mathrm{Gr}$. & 64 & 2638 & 478 & 3116 & 28 & 0 & 28 & 0.44 & 0.90 \\
\hline Total & 298 & 8682 & 2384 & 11066 & 62 & 0 & 62 & 0.21 & 0.56 \\
\hline \multicolumn{10}{|c|}{ 3-3. Free Gingival Smooth Surfaces } \\
\hline $1-2 \mathrm{Gr}$ & 47 & 338 & 197 & 535 & 0 & 1 & 1 & 0.02 & 0.19 \\
\hline $2-3 \mathrm{Gr}$ & 65 & 729 & 260 & 989 & 2 & 0 & 2 & 0.03 & 0.20 \\
\hline $3-4 \mathrm{Gr}$ & 62 & 903 & 254 & 1157 & 3 & 0 & 3 & 0.05 & 0.26 \\
\hline $4-5 \mathrm{Gr}$ & 60 & 1052 & 242 & 1294 & 0 & 0 & 0 & 0.0 & 0.0 \\
\hline $5-6 \mathrm{Gr}$ & 64 & 1319 & 239 & 1558 & 2 & 0 & 2 & 0.03 & 0.13 \\
\hline Total & 298 & 4341 & 1192 & 5533 & 7 & 1 & 8 & 0.03 & 0.14 \\
\hline
\end{tabular}


Table 4 Reduction Rate of Increment of the Carious Lesions by Tea Drinking

\begin{tabular}{|c|c|c|c|}
\hline Cohorts & $\begin{array}{l}\text { Increment } \\
\text { Suhara }\end{array}$ & $\begin{array}{c}\text { Rate in } 9 \% \\
\text { Kamijo }\end{array}$ & Reduction Rate in $9 \mathscr{6}^{*}$ \\
\hline \multicolumn{4}{|c|}{ 1. Pits and Fissures } \\
\hline $1-2 \mathrm{Gr}$ & 6.74 & 17.77 & -62.1 \\
\hline $2-3 \mathrm{Gr}$ & 7.27 & 9.23 & -21.2 \\
\hline $3-4 \mathrm{Gr}$ & 3.53 & 8.27 & -57.1 \\
\hline $4-5 \mathrm{Gr}$ & 3.00 & 8.43 & -64.4 \\
\hline $5-6 \mathrm{Gr}$. & 6.66 & 12.75 & -47.8 \\
\hline Average & 5.29 & 21.19 & -52.7 \\
\hline \multicolumn{4}{|c|}{ 2. Proximal Smooth Surfaces } \\
\hline $1-2 \mathrm{Gr}$ & 0.19 & 0.68 & -72.1 \\
\hline $2-3 \mathrm{Gr}$ & 0.15 & 1.76 & -91.5 \\
\hline $3-4 \mathrm{Gr}$ & 0.61 & 1.22 & -50.0 \\
\hline $4-5 \mathrm{Gr}$ & 0.58 & 1.74 & -66.7 \\
\hline $5-6 \mathrm{Gr}$. & 0.90 & 1.04 & -13.5 \\
\hline Average & 0.56 & 1.29 & -56.6 \\
\hline
\end{tabular}

\footnotetext{
* Reduction Rate $=\frac{\text { Increment Rate at Suhara }- \text { Increment Rate at Kamijo }}{\text { Increment Rate at Kamijo }} \times 100$ $(\mathrm{p}<0.01)$
}

the experimental period of time, with an average increment per child of 1.28 (Table 3).

Out of a total of 11066 intact proximal sites, 62 lesions (0.56\%) or 0.208 lesions on the average appeared up to the final examination (Table 3).

Only 8 lesions $(0.14 \%)$ or a 0.027 average increment appeared on 5533 free gingival sites during the same test period (Table 3 ).

3. Reduction of caries increment by the tea drinking.

The reduction rates were estimated at $52.8 \%$ for pits and fissures and $57.2 \%$ for proximal smooth sites from the differences of increments of lesions appearing in both districts during the test period (Table 4). There was no reduction on free gingival smooth sites.

\section{Discussion}

The results which especially appeared in the reduction rates would denote that, in contrast to the reported results of water fluoridation ${ }^{28,24)}$, tea drinking effected a better reduction in pits and fissures and proximal sites but not on free gingival sites. In regard to the ineffectiveness of the tea drinking on the free gingival sites, however, this might be due to the negligiblely low incidence in Japan. On the contrary, the salient reduction found in pit and fissure lesions should be much more emphasized because these are the most frequent lesions in Japan and tea drinking might help to improve the weak effectiveness of water fluoridation for Japanese children.

The second benifit of the tea drinking could be the low cost/benifit ratio. Bancha is the cheapest tea in Japan as it costs 2 or 3 yen per gram, while the average tea leaves cost 10 times more.

The third benifit of the tea drinking might be that it is more acceptable to the community than water fluoridation. The fourth benifit would be the smaller content of caffein and catechol in bancha than in average tea leaves, which the Japanese do not recommend to children and patients

$$
-18 \text { :- }
$$


hospitalized for a long time; but bancha is given even to a child in the weaning period.

It is important to note here that there was no finding of enamel fluorosis on teeth erupted during the test period; but in this regard, a test on a larger scale is needed.

\section{References}

1) Arif, A. R.: Diet, Fluorine, Tea and Fish. Pakistan Dent. J., $17: 6,1968$.

2) Dean, H. T., P. Jay and F. A. Arnold: Domestic Water and Dental Caries. V., Publ. Health Rep., 57 : 1155, 1942.

3) Arnold, F. A. Jr., H. T. Dean and J. W. Knutson: Effect of Fuoridated Water Supplies on Dental Caries Prevalence; Seventh year of Grand Rapid-Muskegon Study. Public Hlth Rep., 68: 141, 1953.

4) WHO : Twelfth Plenary Meeting. Resolution WHO. 20, 30, 1969.

5) Sita, P. and P. Venkateswarln : Rock Salt : A Probable Dietary Source of Fluoride. J. dent. Res., 46 : 307, 1967.

6) Wespi, H.: Fluor-vollsalz zur Kropf und Karies Bekämpfung. Benno Schwabe Verlag, Basel/Stuttgart, 1956.

7) The Royal College of Physicians of London : Fluoride, Teeth and Health. RCP of London, 1976.

8) Council of Europ. European Public Health Committee, WHO : The Problems of the Implementation of Drinking Water Fluo ridation in Europe. Report of the Working Party. Strasburg, 12-15, May, 1971.

9) Onisi, M., F. Okumura and Y. Murakami : In Vitro Screening of Tea Leaves Effective against Dental Caries. J. Dent. Hlth., 27 : 63, 1978.

10) Cook, H. A. : Fluoride and Tea. Lancet, 1(615), 329, 1969.

11) Cook, H. A. and B. A. France: Fluoride and Tea. Lancet, 1(7974), 1419, 1976.

12) Ramsey, A. C., J. C. Hardwick and J. C. Tamacas: Fluoride Intake and Caries Increments in Relation to Tea Consumption by British Children. (abstract) 21st ORCA Congress, London, 1974.

13) Mummery, R. V.: Levels of Fluoride. Br. Dent. J., 138 : 208, 1975.

14) Eizai Zenji : "Regimen by Tea Drinking" A Commentary by K. Yasui. Meitoku Publ. Co. Ltd., Tokyo, 1974.

15) Onisi, M., M. Kosuge, F. Yoshino, Y. Murakami and T. Tokumasu: Epidemiological Evidence about the Caries Preventive Effect of Drinking Tea. J. Prev. Dent. In Print.

16) Bulletin of Sumon 1975.

17) Onisi, M. and H. Tani: Clinical Trial on the Reduction of Caries Incidence by Use of Two Different Fluoride Dentifrices. J. Dent. Hlth., 20 : 105, 1970. (In Japanese)

18) WHO: Oral Health Surveys. Basic Methods. Geneva, 1971.

19) Imai, Y.: Study of the relationship between Fluorine lons in drinking water and Dental Caries in Japan. J. Dent. Hlth., 22 (2) : 24, 1972.

20) Galagan, D. J. and G. G. Lamson, Jr. : Climate and Endemic Dental Fluorosis. Publ. Health Rep., 68: 497, 1953.

21) Minoguchi, G.: Table of fluoride concentrations (ppm) in drinking water corresponding to CFI (community fluorosis index-Dean) values in different annual temperature zones. Bull. Stomat. Kyoto Univ., 13 : 26, 1975.

22) Nakagawa, C.: Components of the Tea. Food Sciences, Nr. 28, 56, 1976.

23) Reid, D. B. and Grainger, R. M. : Variations in the Caries Susceptibility of Children's Teeth. Human Biology, 27 : 1, 1955.

24) Ludwick, T. G. : Hastings Fluoridation Project. VI. Dental Effects between 1954 and 1970. NZ. Dent. J., $67: 155,1971$.

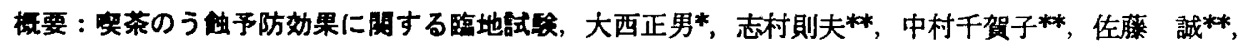
日本で最も安価な番茶のらち，可溶性フッ素を適当に含むものをえらび，新潟県守門村須原小学校児童 298 名に, 毎給食後, 1975 年 12 月から 1976 年 11 月にわたる 1 力年間に, 毎回コップ一杯の茶（約 0.49 $\mathrm{mg} \mathrm{F}$ ) を䄪 250 日与えた。この間に被検児童のう蝕好発部に表われた病变数を, 対照とされた上條地区 の 3 小学校児童 185 名に表われた変化に 比較した。小莒裂瑇で $52.7 \%$, 隣接面で $56.6 \%$ の減少率を得 たが，歯肉寄り唇面では影整がみられなかった。
} 